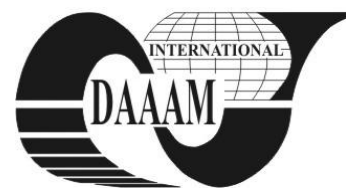

Annals of DAAAM for 2011 \& Proceedings of the 22nd International DAAAM Symposium, Volume 22, No. 1, ISSN 1726-9679 ISBN 978-3-901509-83-4, Editor B. Katalinic, Published by DAAAM International, Vienna, Austria, EU, 2011 Make Harmony between Technology and Nature, and Your Mind will Fly Free as a Bird

\title{
SOLUTION TO EXTEND A CHIMNEY AT INDUSTRIAL POWER PLANT
}

\section{GALEA, A[drian]; GANSCA, S[ebastian] G[heorghe]; RADU HANEA, C[amelia] M[aria]; ROSCA, M[aria] \& TRIF, I[acob] N[icolae]}

\begin{abstract}
The paper presents a practical solution to extend the height of a chimney by doubling the height to increase circulation and improve power plant performance. Starting from an existing industrial chimney, to double the chimney height it's a solution to increase air circulation. Constructive solution proposed for welding materials and manufacturing is the installation of three sections that provide stability by anchoring them, easy

Key words: industrial chimney, welding, fabrication, assembly technology, industrial engineering
\end{abstract}

\section{INTRODUCTION}

For complete and efficient burning of fuel good air circulation is needed. Passing gas through the boiler is made by natural draft, forced draft and draft copies aspiring balanced. Chimney effect creates pressure and the hot gas is transported through the height difference.

Circulation is possible due the difference between atmospheric pressure and static pressure and passing a current of convection in the chimney. Loss of circulation is to reduce static pressure of the combustion gas from the boiler.( Verwiebe, 1996)

Chimney effect is created by the height difference in incoming and outgoing gas. This is due to the difference in density between normal air and heated gases.

\section{THE BOILER FLUE}

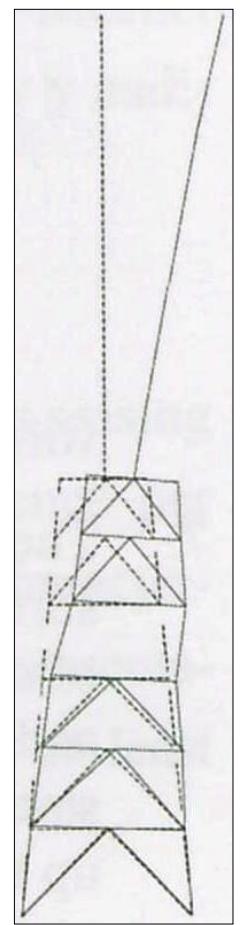

Fig. 1. Extend through a funnel cone
Initially the existing chimney is $42 \mathrm{~m}$ height with a diameter of $5.6 \mathrm{~m}$. Gas before entering the chimney are routed through two electrostatic separators using two pipes with a diameter of $3 \mathrm{~m}$ to enter the chimney at about $25 \mathrm{~m}$ above the ground. (Dilthey, 2004)

Inside the chimney there is a heat exchanger that uses heat from the electrostatic separators and intake air heats the ground. Saturated gas flow from the separator and is mixed with air so it's avoided the creation of a column of visible smoke.

One way to achieve is to extend through a funnel cone like in Figure 1.

\section{SOLUTION TO EXTEND THE CHIMNEY}

To increase efficiency the chimney flue extension is proposed using three columns by double height with a diameter of $4.6 \mathrm{~m}$. For this it was made a supporting frame set in concrete with openings in K. (Eurocode 3, 1993)

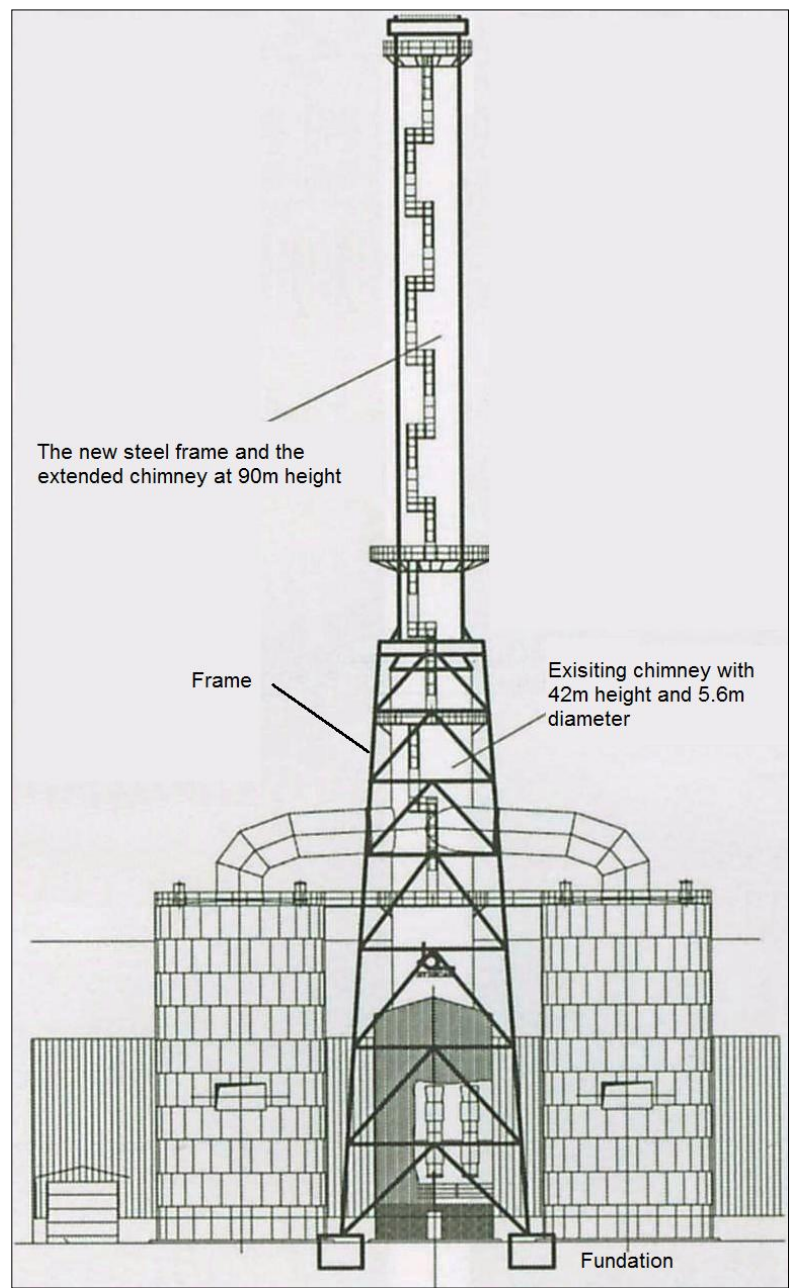

Fig. 2. The solution to extend the chimney 
Figure 2 shows the solution to extend the chimney. It consists of 3 sections each $16 \mathrm{~m}$, each section being made of 4 with generator $2 \mathrm{~m}$ shell rings.

Chimney section is formed by a double shell casing with a diameter of $4.2 \mathrm{~m}$ and a carbon steel column with inner diameter of $4.6 \mathrm{~m}$ stainless steel. Chimney top has a diameter of $5.6 \mathrm{~m}$ and between the two sections of the existing chimney and chimney again is placed a conical section compensator. (Herăscu, 2009)

The first portion of the existing chimney is used as grid support to mount a piece that was included in compensation. Compensator and the three sections of the chimney were built on site with two cranes and joints were made by bolts. Chimney sections were built with access stairs, platforms and dynamic stabilizer to limit time working at height.

Temporary galleries were fixed to the outer shell to provide safe access for installation and tightening the screws

The three sections of the chimney are made in part by welding flux, using a roller block for mechanization of production, and then they were mounted on platforms and stairs giving access to safe access to the installation and maintenance. The three sections were combined and fixed by screws and bolts.

Installation was done with two cranes and anchored by anchor bolts 12 in the column using M36 bolts tensioned and fixed foundation. (Herăscu, 2008)

Figure 3 shows the expanded basket assembly.

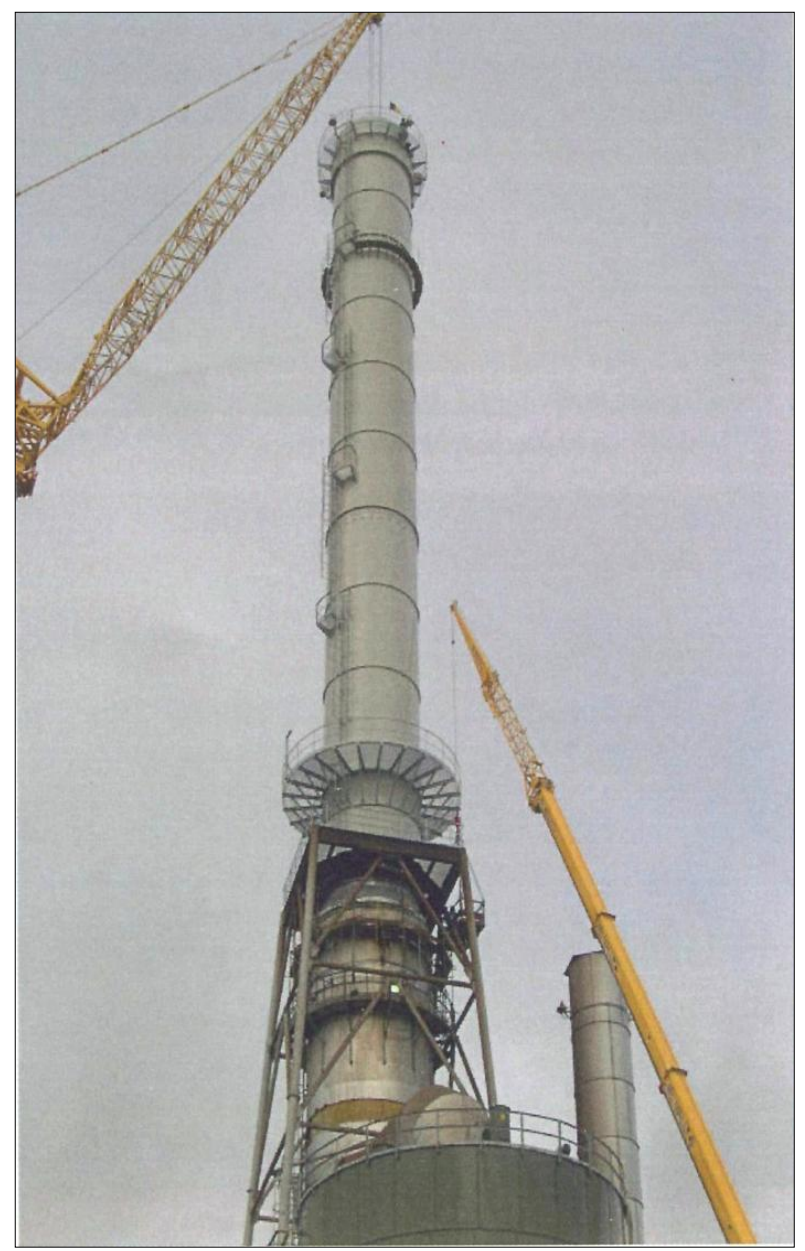

Fig. 3. The expanded basket assembly

\section{ASSEMBLY TECHNOLOGY AND CONTROL OF WELDED OPERATIONS}

Welding columns was achieved by using MAG welding process, which welding wire (with round section) is replaced with strip electrode (wire payment). This method has the advantage of obtaining a much higher melting efficiency, which materializes either a high intake of material deposited, or by a higher welding speed. Welding electrode strip is characterized by the fact that they have better training capacity of the deck over the joints with large openings and has an excellent penetration behavior.

The band is available and the welding is made in the same conditions as those from welding wire round. (Jahromi, 2006)

With this procedure can weld both with short arc and pulsed arc.

If there is a direct comparison between a strip electrode with dimensions of $4.0 \mathrm{~mm} \times 0.5 \mathrm{~mm}$, and round about the same section wire (diameter $1.6 \mathrm{~mm}$ ) can be seen on the perimeter wire an essential difference. While the area is $5.0 \mathrm{~mm}$ round wire, flat wire is that of $9.0 \mathrm{~mm}$, ie about two times higher (79\%). This reflects how the transition (flow) and current transfer filler material and the stitching in the base metal penetration.

\section{CONCLUSION}

To increase the circulation of a chimney is required optimum height and diameter and site specific purpose.

Solution of doubling the existing height of a chimney brings the following advantages:

- Improve plant efficiency by increasing circulation;

- It is more economical than if they would build a new chimney;

- Is an ecological solution;

- Does not require decommissioning only a short time, when there is mounting the flue extension.

\section{ACKNOWLEDGEMENTS}

„ACKNOWLEDGEMENT: This paper is supported by the Sectoral Operational Programme Human Resources Development (SOP HRD), ID76945 financed from the European Social Fund and by the Romanian Government".

„ACKNOWLEDGEMENT: This paper is supported by the Sectoral Operational Programme Human Resources Development (SOP HRD), ID6600 financed from the European Social Fund and by the Romanian Government".

\section{REFERENCES}

Verwiebe, C., Neue Erkenntnisse uber die Erregungmechanismen Regen-wind induzierter Schwingungen, Stahlbau 65 1996, Heft 12

Dilthey U. u.a.: MSG-Schweissen und MSG-Löten von unlegierten Stählen mit Bandelektroden. DVS-Bericht 252, DVS-Verlag, Düsseldorf 2004, S. 111/16

Eurocode 3, Design of Steel Structures, Part 3.1: Towers and Masts, ENV 1993-3-1, June, 1997

Herăscu, M., Cazan recuperator CET Bucureşti Vest, Buletinul AGIR, nr.1/2008

Herăscu, M., Istudor, M., Ghionea, M.C., Trif, I.N., Criterii de calitate la sudarea cazanelor sub presiune, A 8-a Conferinta Internationala de „Tehnologie si Calitate pentru Dezvoltare Durabila" (TQSD) organizatã de U.P.B, 2009

Jahromi, J., S.A., Javadpour, S. and Gheisari, Kh. Failure analysis of welded joints in a power plant exhaust flue, Engineering Failure Analysis,Vol.13, No. 4, pp. 527-536, 2006 